\title{
AZ UNESCO FILMES VÁROSOK ÖSSZEHASONLÍTÓ ELEMZÉSE
}

\author{
IRIMIÁS ANNA \\ A COMPARATIVE ANALYSIS OF UNESCO CITIES OF FILM
}

\begin{abstract}
While cultural and creative industries are at the base of governance models for creative cities, there is a significant lack of understanding with respect to how they contribute to sustainable urban and community development. The UNESCO Creative Cities Network was set up with the aim of providing a cooperation platform for cities for which creative and cultural industries were identified as engines to foster sustainable urban development. In the last fourteen years the network among UNESCO Creative Cities of different size and with diverse historical, political, and social conditions has grown significantly. The purpose of this work is twofold. First, it compares creative cities to detect how urban practices and policies enhance the film industry. Second, it aims to investigate the urban strategies used to enhance social cohesion through film heritage, education, and consumption.
\end{abstract}

Keywords: sustainable urban development, film productions, UNESCO Creative Cities Network

\section{Bevezetés}

A tudásalapú gazdaság mellett a kreatív iparágak meghatározó szereppel bírnak a városfejlődésben (StEvenson, D. 2014, GRODACH, C. 2017). Az UNESCO a kreatív városhálózatot (Creative Cities Network) 2004-ben hozta létre, ma 72 ország 180 városának biztosít együttmúködési platformot (en.unesco.org/creative-cities). A kreativitás alapú városhálózat döntéshozói az irodalom, a gasztronómia, a zene, a dizájn, a kézmúvesség és népmúvészet, valamint a média vagy a film támogatását tartják fenntartható városfejlődésük és megújulási készségük mozgatórugójának (Rosi, M. 2014). Az UNESCO kreatív városhálózathoz a kétévente megrendezésre kerülő pályázaton keresztül lehet csatlakozni. A hálózat egyedülállósága abban rejlik, hogy - a területi dimenziókat figyelembe véve - alulról építkezve a helyi kreatív és kulturális erőforrások versenyképességének megerősítését tartja szem előtt.

A tagság értelmében a város magáénak vallja azt a településfejlődési modellt, amely a fenntarthatóságra, a helyi közösségek jólétére, az örökségek megőrzésére és innovatív fejlesztésére épít (Kovács Z.-SzIRMAI V. 2006). A városok közötti együttmúködés és szakmai támogatás, valamint az UNESCO márka kiszélesítik a stratégiai lehetôségeket, ezáltal mérsékelhetik a területi különbségeket. A pályázó városok méretére és lakosságszámára vonatkozóan nincsenek megkötések, a közös nevezőt a kulturális és kreatív iparágak ösztönzése mellett a városi népesség jólétének figyelembevétele alkotja (BANDARIN F. 2011).

Az elismerés nem csupán egy évre szól, mint a hasonló társadalmi változásokat szorgalmazó Európa Kulturális Fővárosa cím, hanem sokkal inkább egy hosszú távú, a társadalmi integrációs folyamatokat ösztönző elkötelezettség. Az UNESCO hálózatának céljai között szerepel, hogy tagjaik

- a kreatív és kulturális iparágak tehetségeit és vállalkozóit támogassák;

- a társadalmi és kulturális sokszínúséget értékként kezeljék;

- a városok közötti tapasztalatcserét minél szélesebb értelemben szorgalmazzák.

Az UNESCO kreatív városok földrajzi sokszínúségét mutatja, hogy a kézmúvesség és népmúvészet (Crafts and Folk Art) a legkiterjedtebb városhálózattal bíró kreatív iparág, 
európai, afrikai, közel-keleti, délkelet-ázsiai és dél-amerikai városokat szinte egyenlő arányban képvisel. Ezzel szemben a 26 dizájn város túlnyomórészt európai és délkelet-ázsiai városokat köt össze (a volt Szovjetunió tagállamai, köztük Oroszország - a Közel-Kelet városaihoz hasonlóan - teljes mértékben hiányoznak ebből a hálózatból, míg az afrikai kontinenst csupán Fokváros képviseli). A Budapestet is tagjai között tudó dizájn városok közül nyolc (Berlin, Brazíliaváros, Budapest, Helsinki, Mexikóváros, Peking, Szingapúr és Szöul) főváros, bár általában jellemző, hogy az UNESCO kreatív város tagságra a második regionális központok vagy középvárosok pályáznak. Kihívást jelent, hogy hogyan lehet a kreativitást a fenntartható városfejlődés funkcionális komponensévé tenni.

Mielőtt az UNESCO filmes városok (Cities of Film) elemzésére kitérek, érdemesnek tartom megemlíteni, hogy a világ vezető filmgyártó országai India, Kína, az Egyesült Államok és Nigéria (http://uis.unesco.org). India és Kína évi 1000-1500 film készítésével egyrészt a nagy népességszámú belföldi piac és az erősödő középosztály kulturális és szabadidős fogyasztási igényét igyekszik kielégíteni, másrészt az anyaország filmes és televíziós termékei a világ számos országában élő hindu és kínai diaszpóra számára egyfajta nosztalgikus identitáserősító médiumnak is tekinthetők (BANDYOPADHYAY, R. 2008). A filmek, televíziós sorozatok, programok szinte a filmgyártás hajnala óta a puha hatalom (soft power) legbefolyásosabb diplomáciai és propagandisztikus eszközei, amellyel a világ legfóbb gazdaságai élnek is. A harmadik legtöbb filmet gyártó ország az Egyesült Államok, amely termékeit globális szinten magas profittal forgalmazza. 1990 óta Lagos a szubszaharai Afrika videogyártásának központja (LoBATo, R. 2010). Bár a nollywoodi filmek minőségi szempontból ugyan elmaradnak az európai vagy indiai produkcióktól, jelentőségük mégis számottevő, hiszen a nézők szívesen követik az afrikai kultúrához, szokásokhoz és értékrendszerhez kapcsolódó televíziós sorozatokat.

A filmipar a kulturális negyedek városi klaszterein keresztül hozzájárul a városok kulturális és társadalmi megújulásához, képes a városokról alkotott képet befolyásolni, valamint a kulturális turizmust erősíteni (RICHARDS, G. 2014, IRIMIÁs A. 2015a). A hét korábban említett kulturális és kreatív iparág közül a film egyesíti a legkevesebb számú tagot az UNESCO égisze alatt. Meglepő, hogy a filmes városok tagjai között csupán egyetlen kínai várost találunk, Qingdaót. Ugyanakkor sem a korábban említett India sem pedig az Egyesült Államok filmgyártó városai, sem Lagos nem érezték szükségét a kreatív városhálózathoz való csatlakozásnak. Továbbá annak ellenére, hogy a filmgyártás általában a fővárosokban összpontosul, a 13 filmes város közül csupán két európai tag, Róma és Szófia bír fóvárosi ranggal.

A tanulmány célja megvizsgálni, hogy az UNESCO filmes városok milyen intézkedéseket hoztak a kreativitás alapú városfejlesztés érdekében, feltárni, hogy a városhálózaton belül az egymással kialakított kapcsolatok milyen jellegúek, továbbá megvizsgálni, hogy milyen események és kezdeményezések segítik a tapasztalatcserét és ezáltal a városok versenyképességét.

\section{Kreatív városok és a filmgyártás szinergiái}

A városok szimbolikus gazdaságát növeli a kulturális és kreatív iparágak támogatása és gazdasági szerepük elismerése, hiszen olyan árukat vagy szolgáltatásokat alkotnak, amelyek esztétikai és jelképes tartalommal felvértezettek, emellett kereskedelmi értékkel bírnak (ZuKIN, S. 1995). A kreatív gazdaság értelmezése a kulturális gazdaság meghatározásából kiindulva tovább szélesedett és az egyéni kreativitásra és a tudásintenzív munkavégzésre épülő iparágakat is magában foglalja (STEFÁN K.-TRóCSÁNYI A. 2012). 
Az Európai Unióban (EU) a kulturális és kreatív szektor a GDP 4,4\%-át biztosítja. Az EU meghatározása szerint a kulturális és kreatív szektorhoz tartozik minden olyan piac-és nem piacorientált szektor, amelynek alapja a kulturális értékteremtés, illetve a múvészeti és kreatív kifejezésmód. A kulturális és kreatív szektorhoz tartozik az építészet, a levéltárak, könyvtárak és múzeumok, a múvészeti mesterségek, az audiovizuális alkotások (film, televízió, videojátékok, multimédia), a megfogható és megfoghatatlan kulturális örökség, továbbá a dizájn, a fesztiválok, a zene, az irodalom, az előadómúvészetek, a könyvkiadás, valamint a rádió és a vizuális múvészetek. Ezen belül a zene, a dizájn, a képzômúvészet, az irodalom, a média és a filmipar jelentős hozzáadott értékkel rendelkezik (KEA European Affairs 2006). A kreativitás alapú városfejlesztés és a fent említett iparágak közötti kölcsönhatások befolyásolják azokat a dinamikákat, amelyek által a városok kreatív városként határozzák meg magukat (PRATT, A. 2011; ZUKIN, S.-BRASLOW, L. 2011). Vitathatatlan, hogy a kreativitás és kultúra várospolitikai hangsúlyozása a városimázsra (PAPP-VÁRY Á. 2013), a kulturális turizmusra (RÁTZ T. 2006; MichALKó G. 2015), valamint a városi térszerkezetre is hatást gyakorol (EGEDY T. et al. 2018).

A kreativitás alapú városfejlesztés geográfiai vizsgálatának a nemzetközi (PRATT, A. 2000; Scott, A. 2006; Pratt, A.-Hutton, T. 2013; Markusen, A. 2014) és a hazai (Egedy T.-Kovács Z. 2009; Kovács Z. et al. 2011; Stefán K.-Trócsányi A. 2012; EGEDY T. 2017) szakirodalom egyaránt kitüntetett figyelmet szentelt. Az elmúlt évtizedekben a kreatív város elmélete, és főként ideálja több városfejlesztési stratégiát és az ezeket vizsgáló kutatások alapját képezte az Egyesült Államokban (GRODACH, C. 2012), Dániában (LoREnZEN, M.-ANDERSEN, K. 2012) vagy éppen Hongkongban (TANG, W. S. 2016). Ezáltal számos kritika érte azt a városirányítói gyakorlatot, amely Floridát (2002) követve a versenyképes kreatív várossá alakulást nem az alulról építkezésen keresztül, hanem a „sztár-kreatívok” városba csábításával, valamint a tőkeerős felső fogyasztói társadalmi réteg igényeinek szem előtt tartásával kívánta elérni (PRATT, A. 2011). Ez a gyakorlat a városi területek dzsentrifikációjához vezetett (VIVANT, E. 2013). A nagyvárosi koncentráltságot mutató kulturális iparágakra a városfejlődés meghatározó elemeiként tekinthetünk, amennyiben a kis- és középvállalkozások, startupok és szabadúszók arányát és a kulturális infrastruktúrák megépítésének és fejlesztésének mértékét vesszük alapul (Dobó E. 2007; KovÁcs Z. et al. 2011; KeRESENYEI K.-EgEDY T. 2015).

A kulturális és kreatív iparágak közül mind a filmes, mind a televíziós músorgyártás igen jelentős gazdasági húzóágazat, amely jelentős infrastrukturális beruházást igényel, ezért várostervezés szempontjából meghatározó jelentőségű (BoRsos Á. 2010). A filmgyártásban tevékenykedő intézményeknek, vállalkozásoknak és szabadúszóknak szükségük van sűrű személyes hálózatok városi térben való kiépítésére (LEE, N.-RoDRIGUEZ-PoSE, A. 2014). A filmgyártás kulturális és gazdasági szempontból egyaránt meghatározó lehet a városok számára (ENYEDI GY. 2012). Egyes globális várostömörülések, mint pl. a Los Angeles körül kialakult megapolisz, amely Santa Barbarától San Diegóig sokszínú tudás-, film- és televízióiparral rendelkezik, továbbra is meghatározók (FrANK, S. 2012). A kulturális globalizációt a mozi, a televízió, videó és az on-demand tartalomgyártás világhálózata jellemzi. Ezen a területen New York és London vezető pozíciója vitathatatlan, míg az európai filmgyártás további központjai Párizs, Berlin és Milánó.

Európában 2007 és 2016 között több mint 18000 film készült. A koprodukciós kapcsolatoknak, a disztribúciós csatornáknak, valamint a turistákat is vonzó filmfesztiváloknak köszönhetően a film az egyik olyan kulturális iparág, amely erős transznacionális hálózatot képes kialakítani a városok között. A filmgyártás és filmforgalmazás támogatása ez EU országaiban bevett gyakorlat mind országos (adókedvezmények), mind európai (Kreatív Európa Program 2014-2020) szinten. Ez a kitüntetett figyelem egyrészt annak 
tudható be, hogy a filmalkotások kulturális és szórakoztató szerepe kimagasló, másrészt annak, hogy a filmipar tőkeigényes, a megtérülés viszont bizonytalan és magas kockázatú, hiszen nem lehet tudni, hogy egy film sikeres lesz-e a közönség körében vagy sem. Az adókedvezményt - amelynek mértéke Bécsben 20\%, Rómában 25\%, Budapesten 30\%, Amszterdamban 35\% - és közvetlen pénzügyi támogatást kínáló városok a produkciók részleges finanszírozását befektetésként kezelik. A hozam a városban megjelenő egyéb magas költés, amelyet a produkció kelt (pl. kereskedelmi szálláshelyek és szolgáltatások igénybevétele), a helyi munkaerő foglalkoztatása, valamint a város hírnevének erősödése (IRIMIÁs A. 2015b). Olyan filmstúdiók léte, ahol a gyártás mellett az utómunkák elvégzésére is lehetőség van, versenyelőnyt jelent a városok számára (STACHOWIAK, K.-StryjaKiEwicz, T. 2018). A londoni Sohóban vagy az isztambuli Beyogluban a filmgyártást ösztönző városfejlesztés a belvárosi negyedek funkcióváltását idézte elő (DuRMAZ, B. et al. 2010). A szerzők kutatása megerósítette, hogy a filmgyártással foglalkozó cégek az ingatlanbérlési és a parkolási problémák ellenére szívesebben választják a belvárosi negyedeket, mert így közvetlen kapcsolatban lehetnek a filmes szakemberekkel, színészekkel és más kreatív cégekkel, emellett a kereskedelmi és kulturális szolgáltatásokhoz is közel vannak. Ugyanakkor negatív következményekkel is számolni kell. A nagy költségvetésû filmeket csupán kiszolgáló városokban a helyi film- és músorgyártás mértéke elenyésző, ez a filmgyártáshoz kapcsolódó teljes értékláncot bizonytalanná és kiszolgáltatottá teszi (COE, N. 2000; PrATT, A. 2011). Bár a külföldi gyártású filmek támogatása és kiszolgálása a városfejlesztési stratégiák szempontjából rövid távon megtérülő befektetés, hosszú távon nem járul hozzá a városok fenntartható fejlődéséhez. A helyi tehetségek felismerése és támogatása, a helyi filmipar nemzetközi szintú versenyképességének szorgalmazása, a városok kulturális infrastruktúrájának kihasználása döntéshozói összefogást és hosszú távú kreativitás alapú városfejlesztési stratégia kidolgozását teszi nélkülözhetetlenné.

\section{Módszertan}

A szekunder forrásokat feldolgozó kutatás vizsgálati alapját az UNESCO kreatív városhálózat küldetésnyilatkozatának (Mission Statement), a 13 filmes város pályázati anyagának (Membership applications) és a filmes városok honlapjának vizsgálata alkotta. A pályázati anyagokban a kreativitás alapú városfejlesztés fenntarthatóságára vonatkozó célkitûzéseket határozzák meg, ugyanakkor ezek már meglévő kezdeményezésekre, intézményi rendszerre és gyakorlatokra épülnek, amelyeket az UNESCO döntéshozói bizottsága a tagság megítélésekor bírál el. Ennek alapján a filmes városokat önálló szempontrendszer alapján kategorizáltam (1. táblázat).

A tagfelvételt követően négy éven belül monitoring jelentést kell készíteni a megvalósított elképzelésekről, a további akciótervekról, valamint a jó és rossz gyakorlatokról. A jelen tanulmányban ismertetett kutatás idején csupán két város monitoring jelentése érhető el - Bradford Monitoring Report 2016 és Sydney Membership Monitoring Report 2018 -, így ezeket vettem górcső alá.

Mivel a kreativitás alapú fenntartható városfejlesztés tervei és célkitűzései nem korlátozódhatnak a filmes szolgáltatások, infrastrukturális beruházások és kulturális események támogatása köré, ezért - amely város esetében ez lehetséges volt - figyelembe vettem a városok kulturális stratégiai tervét is. A rendelkezésre álló források a Bradford a leading cultural city 2014-2024, A strategy for Bristol culture, Everybody matters: a cultural sustainability strategy framework for Galway 2016-2025 és Sydney cultural policy and 
action plan 2014-2024 voltak. Vizsgálati szempontjaim a kutatási kérdésekben meghatározott szempontokra épültek.

UNESCO filmes városok 2009-2017

(a https://en.unesco.org/creative-cities alapján szerk. IRIMIÁs A.)

UNESCO Cities of Film 2009-2017

(ed. by IRIMIÁs, A. based on https://en.unesco.org/creative-cities)

\begin{tabular}{llll}
\hline A tagság éve & $\begin{array}{l}\text { 1. csoport } \\
\text { (város, ország) }\end{array}$ & $\begin{array}{l}\text { 2. csoport } \\
\text { (város, ország) }\end{array}$ & $\begin{array}{l}\text { 3. csoport } \\
\text { (város, ország) }\end{array}$ \\
\hline 2009 & $\begin{array}{l}\text { Bradford, } \\
\text { Egyesült Királyság }\end{array}$ & Sydney, Ausztrália & \\
2010 & Szófia, Bulgária & & Galway, Írország \\
2014 & & Puszan, Dél-Korea & \\
& & Róma, Olaszország & \\
& & & Bitola, \\
& & & $\begin{array}{l}\text { Észak-Macedónia } \\
\text { Santos, Brazília } \\
\end{array}$ \\
& & & Bristol, \\
& & & Egyesült Királyság \\
& & & Terrassa, \\
& & & Spanyolország \\
& & & \\
& Łódź, Lengyelország & & Yamagata, Japán \\
\hline
\end{tabular}

\section{Eredmények}

\section{Az UNESCO filmes városok kategorizálása}

A városfejlődési stratégia kidolgozása a főpolgármester irányítása alatt és a stakeholderek összefogásával, valamint a döntéshozói folyamatba történő bevonásával jön létre. Kiemelt fontosságú, hogy már a pályázatban átlátható legyen a köz-, a magán- és a civil szféra közötti együttmúködés.

Az UNESCO a filmes városok tagjait több kritérium alapján választja ki. Az értékelő szempontok a következók:

- a városnak a filmgyártáshoz kapcsolódó infrastruktúrája, filmstúdiók megléte;

- a városnak a gyártás, terjesztés és értékesítés területén betöltött szerepe;

- filmmúzeum vagy filmarchívum fenntartása, a filmes örökség megőrzése és innovatív hasznosítása;

- filmfesztiválok, közösségi filmvetítések és más filmhez kapcsolódó események szervezése;

- a helyi és nemzeti filmgyártás ösztönzése; 
- filmes felsôoktatási és szakképzési programok nemzetközi versenyképességének biztosítása;

- a külföldi filmekkel kapcsolatos ismeretek bővítése és a külföldi filmek közönségének társadalmi kiszélesítése.

Bradford, az Egyesült Királyság ötödik legnagyobb városa volt az első filmes kreatív város, majd egy évvel később Sydney csatlakozott a hálózathoz (1. táblázat). 2019-ben már 13 város között múködött tapasztalatcsere, amelynek köszönhetôen számos lehetőség nyílt a helyi filmgyártók és tehetségek elótt.

Az 1. táblázat három csoportba sorolva foglalja össze a 2009-2017 közötti idôszakban kinevezett városokat. Az első csoportba olyan korábbi európai iparvárosok kerültek, amelyek a gazdasági és társadalmi kihívások terén azonosságot mutatnak, ugyanakkor belvárosi területeik átfogó rehabilitációs intézkedéseket igényelnek. Ezek a városok hazájukban egykor elismert filmgyártási központok voltak, jó hírnevú filmes iskolákkal rendelkeztek és filmes örökségük jelentôs múltra tekint vissza.

Az államszocializmus idején Łódź és Szófia a film- és televíziós músorgyártásban igen termékenyek voltak. A világszínvonalú lengyel plakátmúvészetből fejlődött tovább az animációs filmgyártás, Łódź a Se-Ma-For animációs stúdiónak is otthont adott. A Varsói szerződés országai között több koprodukció is létezett, elsősorban lengyel-csehszlovák filmek és sorozatok készültek. Ezeket az alkotásokat a szövetséges országoknak, így Magyarországnak is meg kellett venniük és kötelező volt bemutatniuk. Nem véletlen, hogy a szófiai Boyana Filmstúdió több mint 600 filmet tudott gyártani és ilyen módon forgalmazni. 1990 után a helyzet megváltozott. Lengyelországban a rendszerváltozást követően a mozikban vetített filmeknek csupán 18\%-a volt lengyel, sốt ez az arány 1995-re 10\%-ra csökkent. Ez a gyártott filmek minőségével, a filmes infrastruktúra elmaradottságával, valamint a filmgyártás és terjesztés piacgazdasági feltételeivel és megnövekedett költségeivel magyarázható (STRYJAKIEWICZ, T. et al. 2014). Ugyanakkor a filmiskolákban és egyetemeken tapasztalható humántőke-felhalmozás, a filmgyártásban érintett stakeholderek közötti kapcsolattartás és az innovációra való képesség regionális versenyelónnyel vértezte fel ezeket a városokat.

Úgy vélem, az 1. táblázatban elsô csoportba sorolt városok megkopott fényüket nyerhetik vissza az UNESCO kreatív városhálózati tagság által, amely a helyiek büszkeségét is növelheti. A területi folyamatokat irányító, kreativitás alapú városfejlődési pályák meghatározásában számottevő, hogy Łódź (2016) és Szófia (2019) ugyan sikertelenül, de pályáztak az Európa Kulturális Fơvárosa címre is. Łódź pályázatában a kreatív iparágakhoz kapcsolódó események, rendezvények és beruházások, valamint a nemzetközi városhálózatokban való részvétel különös hangsúlyt kaptak.

A városrendszerüket tekintve igen heterogén második csoportba azok a városok kerültek, amelyek egyrészt nagyvárosok és regionális funkcióval rendelkeznek, másrészt globális szinten is versenyképes filmgyártó központok. Sydney, Puszan, Qingdao és Róma lakosságszámuk és gazdasági szerepük alapján azonos jellegzetességeket mutatnak. Sydney esetében a filmgyártás, filmterjesztés és értékesítés alkotják a város tudásalapú erőforrásbázisát. Az ausztrál filmgyártás, a televíziós sorozatkészítés és az utómunkákhoz kapcsolódó üzleti tevékenység több mint 60\%-a Új-Dél-Wales államhoz és Sydney városhoz kötődik. A filmipar több mint 9000 képzett munkavállalónak nyújt karrierépítési lehetőséget, és a tehetséggondozásban kiemelt figyelmet szentelnek a női rendezők és általában is a női filmes szakemberek támogatására és díjazására. Az ázsiai kikötôvárosok, Puszan és Qingdao paradigmaváltása és urbanizációs fejlődése egyértelmúen a kormányzat kreatív iparágak melletti elkötelezettségéhez és a filmiparhoz kapcsolódik. A kilencvenes évek végéhez köthetô a „Koreai hullám” (Hallyu) születése, amely a koreai kulturális értékeket 
hivatott népszerúsíteni elsősorban az ázsiai térségben. A koreai popzene, a divat, a filmek és sorozatok a Közel-Keleten, Európában és Fekete-Afrika országaiban is igen népszerúek (https://allafrica.com). Puszan 3,5 millió lakossal Dél-Korea második számú regionális központja, a Hallyu filmgyártás fellegvára, a One Asia fesztivál helyszíne. A több mint 9 milliós népességú kínai Qingdao a Sárga-tenger kikötővárosa, filmgyártásának menynyisége és világszínvonalú infrastruktúrája alapján a „Kelet filmstúdiójának” titulálják. A csoportban az egyetlen európai főváros Róma, amely az olasz filmgyártás legendás központja. A római Cinecittà filmstúdió méretét és kiszolgálási kapacitását tekintve egyedülálló. Puszanhoz és Qingdaóhoz viszonyítva az „Álomgyár” építése sokkal korábban, 1937-ben kezdődött, és a hetven évet meghaladó fennállása alatt több mint 3000 film születéséhez asszisztált. Ma már inkább televíziós vetélkedők, sorozatok vagy reklámfilmek forgatási helyszíne. A Római Filmfesztivál is itt kerül megrendezésre.

Megítélésem szerint a második csoportba tartozó megavárosok számára az UNESCO kreatív városhálózata a hollywoodi filmgyártás egyfajta ellenpólusa. A városhálózat tagjai közötti kapocs mutatja a partneri együttmúködés lehetőségét. A filmes városok elkötelezettsége az esélyegyenlőség és a társadalmi integráció iránt megnyilvánul a filmgyártásban érdekeltek társadalmi szerepvállalásában. Ezek a sikeres filmgyártó központok törekednek arra, hogy a kulturális iparág a társadalmi jólét és a fenntartható városfejlődés egyik stratégiai összetevője legyen.

A harmadik kategóriába mérsékelten ismert és periferikus helyzetú középvárosok kerültek, esetükben a kreatív városhálózati tagság magas hozzáadott értékkel rendelkezik és lehetôvé teszi a városok nemzetközi versenyképességének erősítését. Bitola, Terrassa, Santos és Yamagata filmes történeti értékeinek és fesztiváljainak szélesebb körben történő megismertetése hozzájárul a kulturális turizmus élénkítéséhez. Galway és Bristol a kulturális ipar húzóerejét aknázza ki a jó hellyé válás folyamatában. Az átfogó városfejlődési stratégia egyik állomása, hogy Galway 2020-ban az Európa Kulturális Fôvárosa cím birtokosa lesz. Bristol a filmgyártáson belül is specializálódott, ma az európai természetfilmgyártás központjának tartják. Sikerét elsősorban a kis- és középvállalkozásban dolgozó szakembereknek és a BBC elosztó csatornáinak köszönhette (BASSETT, K. et al. 2002). A helyi stakeholdereket bevonó városfejlődési stratégia, a filmes infrastruktúra, a filmgyártást támogató intézményi rendszer jelentik azokat az emberi tényezóket és a tudást alakító intézményeket, melyek Bristol fejlődési pályáját meghatározzák. A kreativitás alapú városfejlődésben továbbá szerepet kap a robotika, a dizájn és a virtuális valóság területéhez kapcsolódó vállalkozásfejlesztés támogatása.

\section{UNESCO filmes városok versenyképessége a filmgyártás terïletén}

A filmgyártásnak otthont adó városok közötti versenyt a nagy költségvetésú produkciók vonzása jelenti. Egy-egy forgatás akár több hónapig is eltarthat, amely jelentôs bevételt eredményezve ezáltal a fogadó város számára. A városban dolgozó filmes produkciók jelenléte továbbá növeli a város népszerúségét, ismertségét a turisták körében. Annak érdekében, hogy minél több nagy produkciót forgassanak egy városban, különböző stratégiák születtek, amelyek közül az egyik legjelentősebb az országos és helyi adókedvezmények biztosítása a produkciók számára. A városok további közvetlen finanszírozási és egyéb támogatási rendszereket vezethetnek be. Mind a 13 UNESCO filmes városban múködik úgynevezett filmtanács, amely egy állami finanszírozású nonprofit szervezet (2. táblázat), és amelynek célja a filmgyártókat a technikai és logisztikai folyamatokban segíteni (IRIMIÁs A. 2015a). A filmtanácsok közvetítő szerepet játszanak a filmgyártók, a helyi filmes szakemberek és vállalkozók között, segítséget nyújtanak a forgatási helyszínek 
kiválasztásához, valamint a forgatáshoz szükséges engedélyek beszerzéséhez, és többen közülük (pl. a Łódźi Filmtanács) pályázati úton pénzügyi támogatásban részesítik azokat a filmeket, amelyeket arra érdemesnek tartanak.

2. táblázat-Table 2

A városok versenyképességét támogató adókedvezmények és filmes infrastruktúra (az egyes városok hivatalos honlapja alapján szerk. IRIMIÁs A.)

Tax rebates and film infrastructure to enhance city's competitiveness (ed. by IRIMIÁs, A. based on the official website of the cities)

\begin{tabular}{lccc}
\hline Város & $\begin{array}{c}\text { Adókedvezmény } \\
\text { mértéke }(\boldsymbol{\%})\end{array}$ & Filmtanács & Filmgyár \\
\hline Bitola & 20 & Bitola Filmtanács & - \\
Bradford & 25 & Bradford Filmtanács & $\begin{array}{c}\text { Prime Studios } \\
\text { (székhely Leeds) } \\
\text { Bristol Film Studios } \\
\text { Bottle Yard Studios }\end{array}$ \\
Bristol & 25 & Bristol Filmtanács & Busan Filming Studio \\
Puszan & 25 & Puszan Filmtanács & Galway Filmközpont \\
Galway & 32 & Eódź Filmtanács & Opus Film \\
Łódź & 30 & Roma Lazio Filmtanács & Square Film Studio \\
Róma & 25 & Wanda Studios & Oriental Movie Metropolis \\
Qingdao & 50 & Santos Filmtanács & - \\
Santos & 0 & Bolgár Nemzeti Filmtanács & Boyana Filmgyár \\
Sofia & 0 & Ausztráliai Filmtanács & Fox Studios Australia \\
Sydney & 40 & Terrassa Filmtanács & Parc Audioviual \\
Terrassa & $15-20$ & Yamagata Filmtanács & - \\
Yamagata & 0 & &
\end{tabular}

A városok profilját vizsgálva elmondható, hogy jelentős területi különbségeket találunk. A 2. táblázat adatai alapján megfigyelhető, hogy a periferikus helyzetű középvárosok vagy kisvárosok, Bitola, Santos és Yamagata kivételével minden filmes városban múködik filmgyár vagy stúdió. A kisvárosokban az alapinfrastruktúra hiánya nem teszi lehetôvé, hogy a filmgyártás a tartós gazdasági fejlődés alappillére legyen. Santos és Yamagata adókedvezményt sem kínál a filmgyártóknak, feltételezhetôen azért, mert talán eddig nem volt rá szükség, mivel kevés nagy költségvetésú produkció kereste ezeket a helyszíneket. Ugyanakkor ezen kreatív városok is képesek kreativitás alapú városfejlődési tendenciák kialakítására a filmes örökség megőrzésével, innovatív fejlesztéssel, fesztiválok rendezésével és a közönségi kör kiszélesítésével. A nagy produkciók kiszolgálására alkalmas filmstúdiók, mint az ausztrál Fox Studios, a koreai Busan Filming Studio vagy a kínai több mint 30 filmstúdiót összpontosító Oriental Movie Metropolis a nemzetközi produkciók gyártása mellett a helyi tehetségek számára is lehetőséget teremtenek a filmkészítésre. A Fox Studiosban forgott az ausztrál filmrendező Baz Luhrmann BAFTA díjas Kötelezoo táncok (1992) címú filmje, vagy az Oscar-díjas Priscilla - A sivatag királynóje (1994). Az amerikai sikerfilm, a Fekete Párduc (2018) egyik forgatási helyszíne Puszan volt. Qingdao filmgyárában készült a kínai filmrendező Zhang Yimou első, amerikai sztárgárdát felsorakoztató epikus fantáziafilmje, A Nagy Fal (2016), melyben Matt Damon játszotta a főszerepet. 
A filmes városok közötti hálózat lényege, hogy a városok közös projekteket dolgozzanak ki, éves találkozókon elősegítsék a tapasztalatcserét, valamint támogassák a helyi tehetségek alkotásainak széleskörű forgalmazását. A partneri kapcsolatok három kategóriába sorolhatók: gazdasági, oktatási és kulturális célú együttmúködések. Ezeket a tagok eltérő mértékben képesek kialakítani és gyümölcsözővé tenni. Az egyik sikeres gazdasági együttmúködés Bradford és Qingdao között jött létre 2017-ben, melyek alapján egy-egy filmtanácsot nyitottak a partnervárosban. A brit kezdeményezésre született megállapodás Bradford számára stratégiai fontosságú, hiszen a nagy költségvetésú kínai filmek jelentős gazdasági bevételt kelthetnek a város számára. Oktatási célú együttmúködések szintén kétoldalú megállapodások alapján rajzolódnak ki: Galway és Róma között kialakult diákcserék lehetôvé teszik, hogy a játék- és dokumentumfilm készítését tanulók nemzetközi tapasztalatokra tegyenek szert. Santos és Bitola minden évben vendégül látják három hétre egymás ifjú tehetségeit és filmkészítőit. Kulturális együttmúködések leginkább a filmfesztiválokhoz kapcsolódó eseményekhez kötődnek, hiszen a minden évben megrendezésre kerülő filmfesztiválokon kiemelt szerepet kapnak a partnervárosok alkotásai. 2017-ben a Puszani Filmfesztivál külön szekcióban mutatta be a Łódź-ból és Yamagatából érkező produkciókat. A 2018-as Santosi Filmfesztivál „Inspiráló városok” címú nyitófilmje egy Santos, Puszan és Frutillar (a zene városa) együttmúködésében készült rövidfilm volt.

\section{UNESCO filmes városok társadalmi szerepvállalása}

Bristol és Sydney négy különböző filmfesztiválnak is otthont adnak. A kreatív városok általában egy nemzetközi és egy dokumentumfilm-fesztivál szervezésében vállalnak szerepet. 2011 óta a Łódź-i Transatlantyk Fesztivál rangos kulturális eseménnyé vált és több mint 65000 érdeklődőt vonz a városba. Bitolában a nemzetközi filmfesztivál, amely a város szülötteinek és a Balkán első filmrendezőinek, a Manaki testvéreknek állít emléket, 1979 óta fogadja a nevezett filmeket. Galway külön projektekkel támogatja a helyi dokumentumfilmes tehetségeket az „Áss, ahol állsz” (Dig where you stand) kezdeményezés keretében. Az infrastrukturális beruházások mellett a filmes városok lépéseket tesznek annak érdekében, hogy piaci pozíciójukat és városimázsukat erósíteni tudják, ez elsősorban a kulturális turizmus attrakciófejlesztéséhez kapcsolódik, másrészt erôsíti a helyi lakosság pozitív percepcióit a várossal kapcsolatban. A külföldi tehetséget is vonzó filmiskolák, mint pl. a Łódź-i Nemzeti Film-, Televízió- és Színháziskola, vagy a Sydney Filmiskola, továbbá a látogatóközpontként is múködő filmmúzeumok és filmarchívumok (a puszani és qingdaói Filmmúzeum, valamint a római Cinecittá) egyrészt gerjesztôi a filmkészítéssel foglalkozók mobilitásának, másrészt vonzerőként szolgálnak a városba érkező turisták számára. Jól érzékelhetô ez az 1. ábrán, amely a filmes városokban megrendezésre kerülő filmfesztiválok, a filmmúzeumok, a filmarchívumok és a filmes oktatás intézményeinek számát szemlélteti.

Az UNESCO kreatív városhálózat egyik alappillére a társadalmi integráció előmozdítása. A hálózat tagjai heterogén csoportot alkotnak, jelentősen eltérő lakosságszámmal rendelkeznek, gazdasági szempontból széles sávban mozognak, városfejlődésük társadalmi, építészeti és döntéshozói oldalról nézve egyaránt eltérő, és bennük különböző válságjelek érzékelhetők. A fenntartható városfejlődés szempontjából több kritikus pont is említhető: szegénység, munkanélküliség és kirekesztettség. A kreativitás alapú városfejlődés ezen társadalmi problémákat felismeri és városfejlesztési stratégiájában kezelési lehetôségeket vázol fel. A filmes programok, események és kezdeményezések nyilvánvalóan nem tudják orvosolni a szegénységet, de a szegénységhez szorosan kötődő kirekesztettség egyes tüneteire gyógyírt tudnak nyújtani. A brazíliai Santos a peremre szorult és kiszolgáltatott 


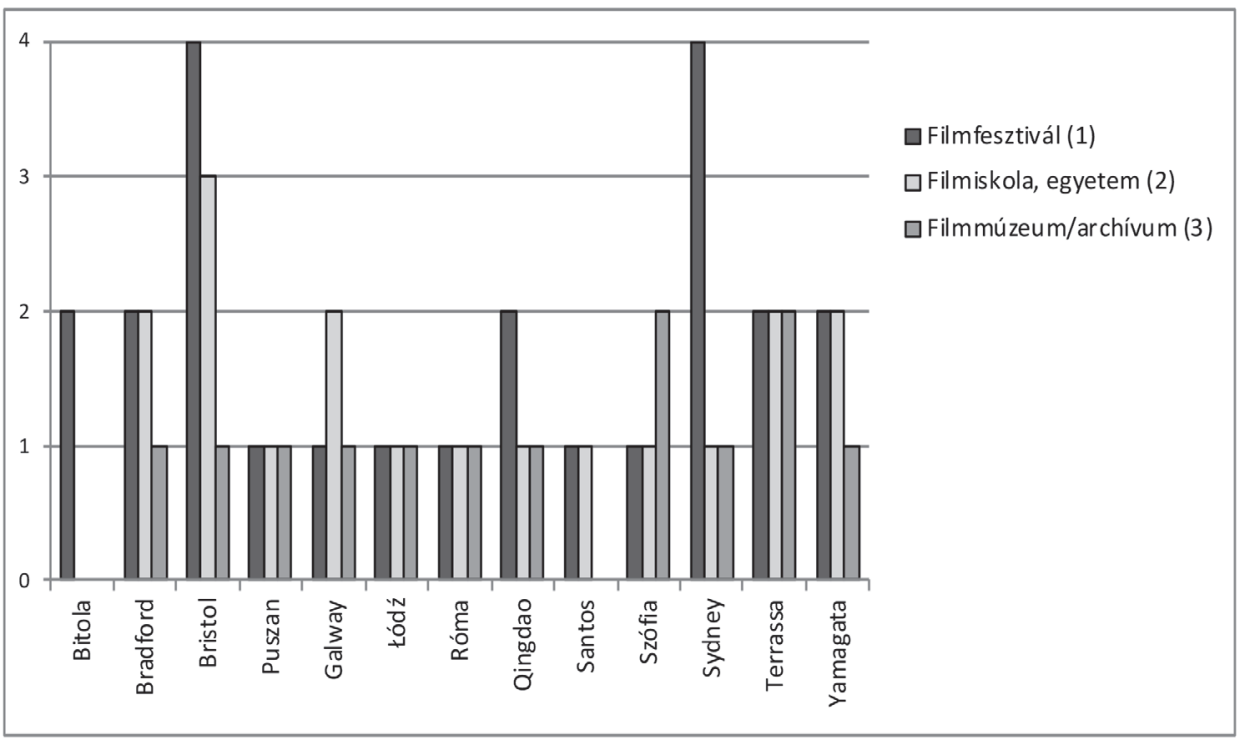

1. ábra UNESCO filmes városok filmekhez kapcsolódó kulturális és oktatási eseményei és intézményei (a városok honlapjai és https://en.unesco.org/creative-cities alapján szerk. IRIMIÁs A.).

Jelmagyarázat: 1 - filmfesztivál; 2 - filmiskola, filmegyetem; 3 - filmmúzeum, filmarchívum

Figure 1 Film-related cultural amenities and educational opportunities in UNESCO cities of film

(ed. by IRIMIÁs, A. based on the official website of the cities and https://en.unesco.org/creative-cities). Legend: 1 - film festival; 2 - film school, film university; 3 - film museum, film archive

társadalmi csoportok felzárkóztatásán dolgozik. Küldetése, hogy a hátrányos helyzetú fiatalok is megismerkedhessenek a filmkészítéssel és megfelelő oktatási irányítás mellett elkészíthessék és bemutathassák saját alkotásaikat. Bradford, Bristol és Galway az eltérô etnikumú és kultúrájú csoportok beillesztését tűzte ki célul. A szolidaritást, a befogadást és a megismerést szorgalmazzák azok az ingyenes és rendszeres szabadtéri filmvetítések, filmklubok és események, amelyek egyaránt szólnak fiataloknak, családoknak és időseknek. A filmek által lehetôség nyílik kultúrák megismerésére, élethelyzetek átérzésére, valamint közös szórakozásra. Az eltérő generációkat és társadalmi csoportokat összekapcsoló kommunikáció és élménymegosztás az interkulturális érzékenység növelésén keresztül a társadalmi jólét előmozdításához járul hozzá.

\section{UNESCO kreatív városhálózat Közép-Európában és a Balkánon}

A közép-európai térségben az UNESCO kreatív városhálózatának négy fóvárosi településegyüttes (Prága, Budapest, Ljubljana, Szófia) és öt másodrendú regionális központ (Kaunas, Katowice, Kassa, Linz, Bitola) mellett olyan közepes és kisvárosok, mint Krakkó, Łódź, Brno, Graz, Gabrovo a tagjai (2.ábra). A gasztronómián kívül minden kulturális és kreatív iparág képviselteti magát. Lengyelország három, Csehország és Ausztria két kreatív városi tagot is számlál. A kreatív városok közötti szinergiákat az együttmúködések, zászlóshajós események közös szervezése, valamint rendszeres tapasztalatcsere erősítik, hozzájárulva ezáltal az UNESCO városhálózat vitalitásának megőrzéséhez.

Az egykori bányászati központ, Katowice évente 27 zenei fesztiválnak ad otthont, zeneiskolája és jazzfesztiválja világhírú. Krakkó az irodalom városa, a könyvkiadás (több mint 100 könyvkiadóval és 75 független könyvesbolttal) a térség egyik húzóágazata. 


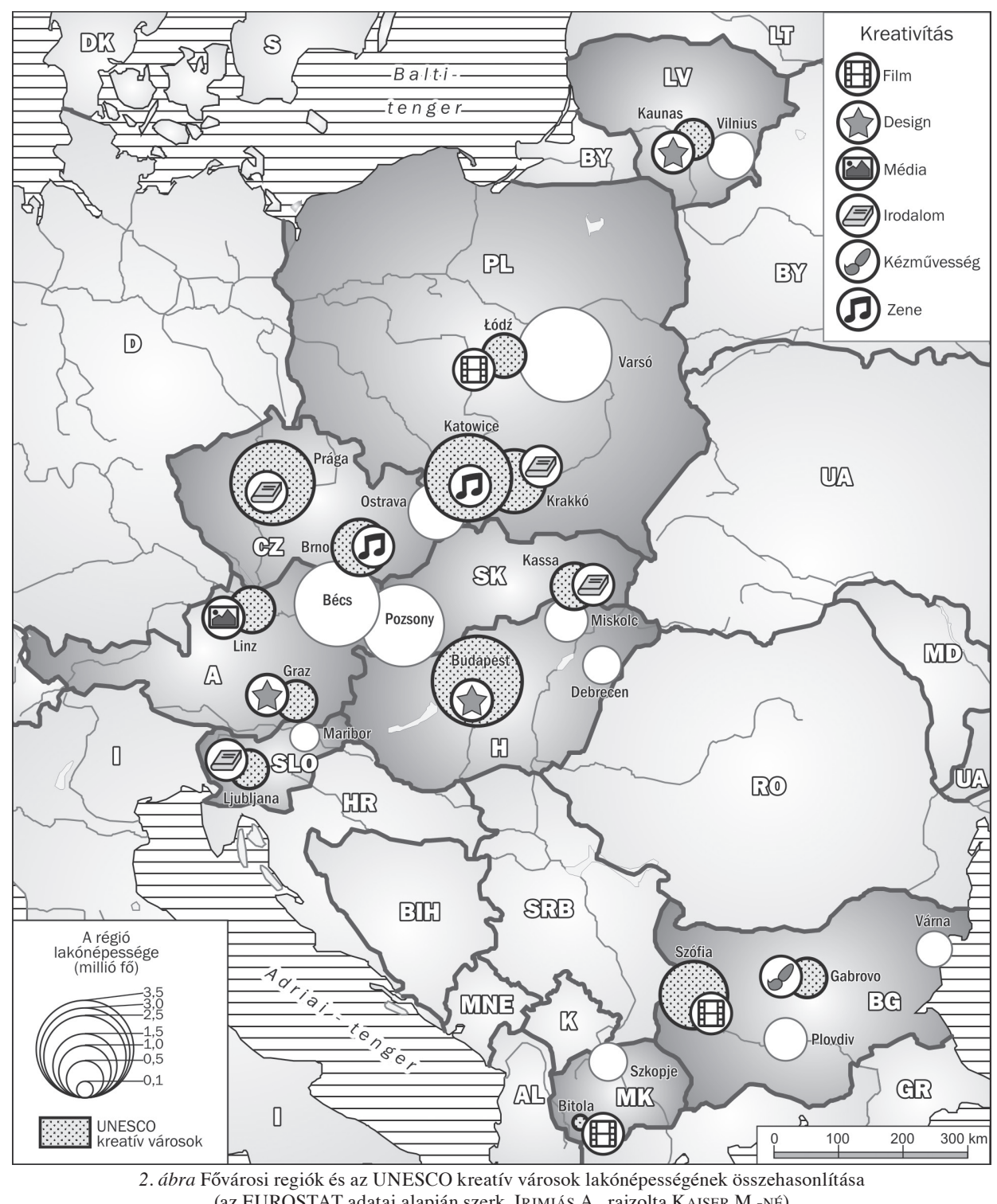

Figure 2 The population of the capital city metropolitan regions compared with the population of the UNESCO Creative Cities (ed by IrIMIÁs, A. based on EUROSTAT, designed by KAISER, M.-NÉ)

A kreativitás alapú városfejlődési stratégia alapja a társadalmi integráció. Számos irodalmi fesztivált szerveznek, egységes könyvtári kölcsönzőrendszert építettek ki, irodalmi és kreatív írói foglalkozásokat nyújtanak kórházi betegeknek és fogvatartottaknak. Továbbá a három lengyel kreatív város közös eseményeket és konferenciákat is szervez. A bolgár filmes város Szófia, a 2017-ben tagságot kapott Gabrovóval (kézmúvesváros) alakított ki együttmúködéseket, amelyek hozzájárulhatnak a területi különbségek mérsékléséhez. 


\section{Összefoglalás}

A kulturális és kreatív iparágak, mint például a film, számos területen képesek előmozdítani egy-egy város újrapozícionálását, kreatív infrastruktúrájának megújítását, gazdasági és társadalmi fejlődését. A presztízsértékú UNESCO kreatív városhálózati tagság azt is bizonyítja, hogy a városok döntéshozói, a köz- és civil szféra képviselői, a vállalkozói szervezetek, az oktatási intézmények és a kulturális attrakciók vezetôi képesek nemzetközi és regionális városhálózatokat kialakítani, és ezáltal a kreativitásra épülő térbeli hatásmechanizmusokat elindítani. A kreatív városok között nyilvánvalóan megfigyelhető egyfajta térbeli fejlettségi tagoltság, ugyanakkor az UNESCO városhálózathoz való csatlakozás az együttmúködésre épülő szinergiahatásokat és nem a térségek versenyét erôsíti. Közép-Európában emellett megfigyelhető, hogy a 14 kreatív város között alulreprezentáltak a fơvárosok. Ez ellentmond annak a gyakori elképzelésnek, hogy a kreatív iparágak csupán a fővárosokban képesek kreativitás alapú városfejlődési folyamatok indítására. A közép-európai városok számára a hálózat lehetőséget biztosít nemzetközi kapcsolatok kiépítésére és közös értékeket képviselő kreatív szakemberek közötti tapasztalatcserére.

Az UNESCO filmes városok rövid elemzését követően elmondható, hogy a városok elismerik a kulturális és kreatív iparágak sajátosságait, és képesek olyan városfejlődési stratégia kidolgozására és gyakorlatba ültetésére, amely a filmszektorban felhalmozott tudástőkére, filmes örökségre és azok innovatív fejlesztésére, valamint más kreatív iparágakkal történő hibridizációjára épít. Ezért kitüntetett figyelemmel kezelik a helyi kreatív és kulturális erőforrások versenyképességének megerősítését, a filmkultúrához és filmgyártáshoz kötődő oktatás támogatását, élénk kulturális élet ösztönzését, valamint a társadalmi szolidaritás szorgalmazását. A partneri együttmúködések keretében konkrét formában jön létre az oktatás, a koprodukciók gyártása és a filmek nemzetközi fesztiválokon történő bemutatása által.

A társadalmi térbeliség szempontjából fontos megemlíteni, hogy a foglalkoztatási struktúrát tekintve a filmiparban tevékenykedő kis- és középvállalkozók, szabadúszók és filmes tehetségek támogatása nem megoldott, emiatt jellemzően kénytelenek határozott idejü projektmunkákon dolgozni, amelyek kiszámíthatatlanok és nem teszik lehetôvé a hosszú távú tervezést és vállalkozásfejlesztést. A kreatív iparágakban keletkezett munkahelyek jelentős részét fiatalok töltik be, akik foglalkoztatása sokszor nem megfizetett azon indok alapján, hogy így tapasztalatot gyújthetnek és kapcsolatokat építhetnek. Az UNESCO kreatív városhálózata fellép ezen gyakorlatok ellen, és az ENSZ Fenntartható Fejlödési Keretrendszer 2030 szempontjait követve védik a bizonytalan foglalkoztatási viszonyban dolgozók jogait.

Végezetül megemlítem, hogy az UNESCO kreatív városhálózat csupán 14 éve alakult, így a jövőben szükséges egy teljes keresztmetszetú összehasonlító esettanulmány, amely vizsgálja a kreatív iparágakra épülő társadalmilag fenntartható városfejlődés tapasztalatait.

\section{Köszönetnyilvánítás}

A kutatást az MTA Bolyai János Kutatási Ösztöndíj pályázata támogatta.

IRIMIÁS ANNA

Budapesti Corvinus Egyetem, Budapest

anna.irimias@uni-corvinus.hu 


\section{IRODALOM}

BANDARIN, F. 2011: The creative power of cities. - City, Culture and Society 2. pp. 121-122.

BANDYOPADHYAY, R. 2008: Nostalgia, identity and tourism: Bollywood in the Indian diaspora. - Journal of Tourism and Cultural Change 6.2.pp. 79-100.

BassetT, K.-GRiffiths, R.-SMith, I. 2002: Cultural industries, cultural clusters and the city: The example of natural history film making in Bristol. - Geoforum 33. pp. 165-177.

Borsos Á. 2010: Filmföldrajz, az új tudományterület? - Földrajzi Közlemények 134. 4. pp. 419-430.

CoE, N. M. 2000: The view from out West: embeddedness, inter-personal relations and the development of an indigenous film industry in Vancouver. - Geoforum 31. pp. 391-407.

Doвó E. 2007: A globalizáció és a kreatív gazdaság felértékelődése. - Tér és Társadalom 21. 3. pp. 89-102.

Durmaz, B.-Platt, S.-Yigitcanlar, T. 2009: Creativity, culture tourism and place-making: Istanbul and London film industries. - International Journal of Culture, Tourism and Hospitality Research 4. 3. pp. 198-213.

EGEDY T. 2017: Városfejlesztési paradigmák az új évezredben. A kreatív város és az okos város. - Földrajzi Közlemények 141.3.pp. 254-262.

EgEdy T.-KovÁcs Z. 2009: The potentials of Budapest to attract creativity. The view of high-skilled employees, managers and transnational migrants. - ACRE Report 8. 4. University of Amsterdam, Amsterdam.

EGEDY T.-KovÁCs Z.-SzABó B. 2018: Changing geography of the creative economy in Hungary at the beginning of the $21^{\text {st }}$ century. - Hungarian Geographical Bulletin 67. 3. pp. 275-291.

EnYEDI Gy. 2012:Városi világ. - Akadémiai Kiadó, Budapest. 186 p.

FLORIDA, R. 2002: The rise of the creative class. - Washington Monthly, May. pp. 15-25.

FRANK, S. 2012: Claiming Hollywood: Boosters, the film industry and the metropolitan Los Angeles. - Journal of Urban History 38.1. pp. 71-88.

GRODACH, C. 2012: Before and after the creative city: The politics of urban cultural policy in Austin, Texas. Journal of Urban Affairs 34. pp. 81-97.

GRODACH, C. 2017: Urban cultural policy and creative citymaking. - Cities 68. pp. 82-91.

IRIMIÁs A. 2015a: Filmturizmus. A filmek és televíziós sorozatok turisztikai szerepének és hatásainak geográfiai vizsgálata. - Akadémiai Kiadó, Budapest. 236 p.

IRIMIÁs A. 2015b: Business tourism aspects of film tourism: The case of Budapest. - Almatourism 6. 4. pp. 35-46.

KEA European Affairs 2006: The economy of culture in Europe. - European Commission DG5, Brüsszel.

KERESENYEI K.-Egedy T. 2015: Adalékok a kreatív gazdaság elméletéhez. - Földrajzi Közlemények 139. 1. pp. $30-42$.

KovÁcs Z.-EgEdy T.-SzABó B. 2011: A kreatív gazdaság földrajzi jellemzői Magyarországon. - Tér és Társadalom 25. 1. pp. 42-62.

KovÁcs Z.-SzIRMAI V. 2006: A városrehabilitációs beavatkozások és a térbeli társadalmi kirekesztés: a társadalmilag fenntartható városfejlődés budapesti lehetőségei. - Tér és Társadalom 20. 1. pp. 1-19.

LeE, N.-Rodriguez-Pose, A. 2014: Creativity, cities and innovation. - Enviroment and Planning A: Economy and Space 46. pp. 1139-1159.

LoBATO, R. 2010: Creative industries and informal economies: Lessons from Nollywood. - International Journal of Cultural Studies 13. 4. pp. 337-354.

LorenZen, M.-Andersen, K. V. 2012: Different creative cities: Exploring Danish data to adapt the creative class argument to small welfare economies. - Creative Industries Journal 4. 2. pp. 123-136.

MARKUSEN, A. 2014: Creative cities: A 10-year research agenda. - Journal of Urban Affairs 36. 2. pp. $567-586$.

Michalkó G. 2015: A városimázs és a jól-lét alapú társadalmi versenyképesség. - In: SziRMAI V. (szerk.): A területi egyenlőtlenségektől a társadalmi jól-lét felé. Kodolányi János Főiskola, Székesfehérvár. pp. 349-371.

PAPP-VÁRY Á. 2013: A márkanév ereje. Szempontok a sikeres brandépítéshez. - Dialóg Campus, Pécs-Budapest. $320 \mathrm{p}$.

Pratt, A. C. 2000: New media, the new economy and new spaces. - Geoforum 31. 4. pp. 425-436.

PratT, A. C. 2011: The cultural contradictions of the creative city. - City, Culture and Society 2. pp. 123-130.

Pratt, A. C.-Hutton, T. A. 2013: Reconceptualising the relationship between the creative economy and the city: Learning from the financial crisis. - Cities 33. pp. 86-95.

RÁTz T. 2006: Kulturális turizmus és városfejlesztés - Európa Kulturális Fővárosa. - Turizmus Bulletin 10. 2. pp. $9-15$.

RICHARDS, G. 2014: Creativity and tourism in the city. - Current Issues in Tourism 17. 2. pp. 119-144.

Rosi, M. 2014: Branding or sharing? The dialectics of labelling and cooperation in the UNESCO Creative Cities Network. - City Culture and Society 5. pp. 107-110.

Scotт, A. J. 2006: Creative cities: Conceptual issues and policy questions. - Journal of Urban Affairs 28. 1. pp. 1-17. 
STACHOWIAK, K.-STRYJAKIEWICZ, T. 2018: The rise of film production locations and specialised film services in European semi-peripheries. - Hungarian Geographical Bulletin 67. 3. pp. 223-237.

Stefán K.-TRócsánYi A. 2012: Geographic aspects and spread of the cultural economy in Hungary. - In: TRócsánYi A.-PIRISI G. (szerk.): The role of the cultural economy and tourism in the renewal of cities. University of Pécs, Pécs. pp. 89-106.

Stevenson, D. 2014: Cities of Culture. A global perspective. - Routledge, Oxon. 175 p.

Stryjakiewicz, T.-MĘCZyŃski, M.-Stachowiak, K. 2014: Role of creative industries in the post-socialist urban transformation. - Quaestiones Geographicae 33. 2. pp. 19-35.

TANG, W. S. 2016: Creative industries, public engagement and urban redevelopment in Hong Kong: Cultural regeneration as another dose of isotopia? - Cities 56. pp. 156-164.

Vivant, E. 2013: Creatives in the city. Urban contradictions of the creative city. - City, Culture and Society 4. pp. 57-63.

Zukin, S. 1995: The cultures of cities. - Blackwell Publishing, Malden. 338 p.

Zukin, S.-BRASLOW, L. 2011: The life cycle of New York's creative districts: Reflections on an unanticipated consequences of unplanned cultural zones. - City, Culture and Society 2. pp. 131-140.

\section{Online források}

Bradford Monitoring Report 2016

https:/en.unesco.org/creative-cities/sites/creative-cities/files/UNESCO\%20Bradford\%20City\%20of\%20 Film\%20Report\%202016\%20\%281\%29.pdf

Utolsó letöltés dátuma 2019. február 12.

Bradford a leading cultural city 2014-2024 https://www.bradford.gov.uk/media/2708/bradfordculturalstrategyjune2014.pdf Utolsó letöltés dátuma 2019. február 12.

A strategy for Bristol culture https://democracy.bristol.gov.uk/documents/s14586/Appendix\%20A2\%20-\%20Bristol\%20Cultural\%20 Strategy.pdf

Utolsó letöltés dátuma 2019. február 12.

Galway:http://galwaycitycommunitynetwork.ie/everybody-matters-a-cultural-sustainability-strategy-framework -for-galway-2016-2025/

Utolsó letöltés dátuma 2019. február 12.

Sydney Membership Monitoring Report 2018 https://en.unesco.org/creative-cities/sites/creative-cities/files/monitoring_reports/unesco_monitoring_ report17_sydney.pdf Utolsó letöltés dátuma 2019. február 12.

Sydney cultural policy and action plan 2014-2024 https://www.cityofsydney.nsw.gov.au/__data/assets/pdf_file/0011/213986/11418-Finalisation-of-Cultural-Policy-Document-July-2016.pdf Utolsó letöltés dátuma 2019. február 12.

UNESCO Creative Cities Network https://en.unesco.org/creative-cities/home Utolsó letöltés dátuma 2019. február 12. 